\title{
Septal deviation and other factors increase the risk of barotitis media in high altitude high opening training
}

\author{
Yanuar T Sastranegara, ${ }^{1,2}$ Bastaman Basuki, ${ }^{2}$ Herman Mulijadi ${ }^{1}$
}

\begin{abstract}
Abstrak
Akibat perubahan tekanan yang cepat, Barotitis media (BM) sering juga terjadi pada latihan simulasi terjun High Altitude High Opening (HAHO). Penelitian bertujuan untuk mengidentifikasi faktor deviasi septum dan beberapa faktor lain terhadap peningkatan risiko BM. Pada penelitian eksperimen ini subjek terdiri dari anggota TNI yang melaksanakan latihan HAHO di Lembaga Kesehatan Penerbangan dan Antariksa (Lakespra Saryanto) selama Mei - Juli 2007. Pemeriksaan fisik dilakukan sebelum latihan. Dan pemeriksaan BM setelah latihan oleh peneliti dan dokter spesialis THT. Data diolah dengan uji regresi Cox menggunakan program STATA 9.0. Subyek penelitian sebanyak 177 orang, dan di antaranya (56,5\%) mengalami BM setelah latihan. Deviasi septum ditemukan pada $28,8 \%$ subjek. Subjek yang menderita dengan dibandingan dengan yang tidak menderita septum deviasi mempunyai risiko 23\% lebih besar terkena $B M[R R$ suaian $(R R a)=1,23 ; 95 \%$ interval kepercayaan $(95 \%$ IP $)=0,95-1,60 ; p=0,123]$. Perokok 1-3 tahun mempunyai risiko $68 \%$ lebih banyak terkena BM dibandingkan yang tidak merokok $(R R a=1,68 ; 95 \%$ IP $=1,17-2,42 ;$ $p=0,005)$. Subjek dengan masa dinas lebih dari 5 tahun dibandingkan masa dinas kurang dari 5 tahun mempunyai risiko 50\% lebih besar. Di samping itu, calon siswa atau siswa HAHO mempunyai risiko $40 \%$ lebih besar mengalami BM dibandingkan yang memiliki kualifikasi HAHO (RRa = 1,40; 95\% IP = 0,99 - 1,97; $p=0,051)$. Pada latihan terjun HAHO, untuk mengurangi risiko BM diperlukan perhatian khusus terhadap subjek yang memiliki kelainan deviasi septum, masa dinas yang lama, merokok 1-3 tahun, dan calon siswa serta siswa penerjun HAHO. (Med J Indones 2008; 17: 37-42)
\end{abstract}

\begin{abstract}
Barotitis media (BM) frequently occurr in High Altitude High Opening (HAHO) training simulation as a result from rapid change of pressure. The aim of this study was to investigate septal deviation and other risk factors that increase the risk of BM. This experimental study was conducted at the Indonesian Center for Aviation Medicine and Health (Lakespra Saryanto) during May - July 2007 involving Indonesian Armed Forces (TNI) HAHO training. Medical examinations were performed before and after training. An otolaryngologist confirm the diagnosis of BM. Cox regression analysis using STATA 9.0 program was performed to identify dominant risk factors for BM. A number of 177 subjects participated in this study. We found $56.5 \%$ had BM after training. Septal deviation was found in $28.8 \%$ of the subjects and it moderately increased the risk of BM by 23\% than normal septum [adjusted relative risk $(R R a)=1.23 ; 95 \%$ confidence interval $(C I)=0.95-1.60 ; p=0.123]$. Those who have been smoking for 1-3 years had $70 \%$ increase risk for BM than non-smoking subjects $(R R a=1.68 ; 95 \% C I=1.17-2.42)$. Those who have been in the force for 5 years or longer were $50 \%$ more at risk for BM than those who have been in the force less than 5 years. In addition, trainees had $40 \%$ higher risk than subjects with special qualifications for HAHO $(R R a=1.40 ; 95 \% C I=0.99-1.97 ; p=0.051)$. Special caution need to be applied for those who had septal deviation, longer working period, habit of smoking for 1-3 years, and trainees to minimize the risk of BM. (Med J Indones 2008; 17: 37-42)
\end{abstract}

Keywords: barotitis media, septal deviation, HAHO training simulation.

Barotitis media (BM) is a frequent problem in aviation that results from a rapid change of ambient pressure such as in High Altitude High Opening (HAHO) training simulation. This is a disturbance of pressure equalization in the middle ear in the form of BM characterized by

\footnotetext{
${ }^{1}$ Indonesian Center for Aviation Medicine and Health, Jakarta, Indonesia

${ }^{2}$ Department of Community Medicine Faculty of Medicine University of Indonesia, Jakarta, Indonesia
}

the un-opening of the Eustachian tube (ET).$^{1-3}$ A pevious study of HAHO simulation training at the Indonesian Center for Aviation Medicine and Health (Lakespra Saryanto) revealed the incidence of BM was $48.8 \%$ and septal deviation was the most common ear nose and throat (ENT) problem (Lersonal comunication, Lakespra). Personal skills of maneuvers to prevent $\mathrm{BM}$ will reduce the risk of BM. Unfortunately, not all individuals can do the maneuvers correctly, therefore $\mathrm{BM}$ is still common and it can be worsed by the 
presence of ENT problems. ${ }^{4,5}$ In addition, smoking was suggested to be another risk factor for BM. Several ENT disorders are related to BM, but septal deviation is the most common ENT problem related to BM.

HAHO freefall is one of training many military techniques of intercepting the enemy zone by freefalling from a very high altitude and opening the parachute at a high altitude. The HAHO personel has a risk of rapid ambient pressure change particularly at the time of freefall until the preferred altitude is reached. ${ }^{1}$ In order to identify risk factors related to $\mathrm{BM}$, we performed a study at HAHO training simulation, which is a simulation of the pressure changes in a hypobaric chamber. This type of training can be used for selection of aircrew for freefalling. The aim of this study was to identify septal deviation and other factors that increase the risk of BM.

\section{METHODS}

This experimental study was conducted at Lakespra Saryanto, during the period of May-July 2007. Subjects were aircrew, freefall or trainees of Indonesian armed forced (TNI) who have had aerophysiology indoctrination training (ILA) or passed the selection test in the hypobaric chamber with HAHO simulation. Those who had any of these conditions: otitis media, severe pharyngitis, severe rhinitis, severe sinusitis, did not pass the examination test or could not perform the valsava maneuver.

For this study we used equipment such as: (1) Lakespra's ETC ${ }^{\circledR}$ Hypobaric chamber made in USA in 1981; (2) A Riester ${ }^{\circledR}$ Othoscope to examine the subjects for BM.

The study process. The intervention was the HAHO training simulation which was freefalling from altitude of 25,000 to 8,000 feet with a descending rate of 10,000 feet/minut, followed by freefalling from 8,000 feet to ground level (GL), with a decending rate of 1,000 feet/minut.

The examination of the tympanic membrane (TM) was performed right before the simulation began and immediately after the simulation was over by the investigators accompanied with an experienced Otholaryngologist.

The study steps were: (1) Physical examination by General Physician (GP) and Otholaryngologist; (2) briefing for participants before training on aviaton medicine, the $\mathrm{BM}$ problems, how to prevent $\mathrm{BM}$, and explanation on the study; (3) Valsava maneuver checked by investigators before training, to assure that the participants are able to do the maneuver, by direct examination with an othoscope to see the TM movement while the maneuver was performed.

The simulation steps: (a) The participants used a mask, checking the PRICE (Pressure, Regulator, Indicator, Connector and Emergency) to confirm the oxygen supply; (b) climb to 5,000 feet with a climbing rate of 5,000 feet/minute to perform sinus check. In case a subject had sinus block or ear block, he will be handled right away; (c) descend to GL with decending rate of $5,000 \mathrm{ft} / \mathrm{mnt}$, someone with sinus or ear block at this phase will be excluded; (d) climb to 25,000 feet, perform a hypoxia demonstration by doing simple math tasks; (e) after that all participants use $100 \%$ oxygen; (f) HAHO began, descending from 25,000 to 8,000 feet with 10,000 feet/minut decending rate. Then on for a while at 8,000 feet to handle any problems that might have occurred; (g) after all the problems were handled they begin to decend to GL at 1,000 feet/minut decending rate; (h) all the problems which occurred during the training session were handled by the observer inside the chamber; (h) BM examination was performed immediately after the training was finished, and therapy was given as needed; (i) filling in the of questionaires.

Barotitis media. In this study BM was defined as an acute inflammation in the middle ear caused by pressure change which was confirmed by the presence of injection or hyperemic of TM and can be accompanied by a feeling of fullness, pain, tinnitus or vertigo. ${ }^{1-3,7}$

ENT disorders were ENT disorders that resulted from infection, allergic anatomical abnormality and confirmed by an otholaryngologist. The disorders consisted of septal deviation, pharyngitis, rhinitis, tonsillitis and sinusistis. ${ }^{13-4}$

Behaviour. Defined as the ability of the subject to perform preventive maneuvers of $\mathrm{BM}$ at the appropriate time. Smoking period. Defined as the time length of the subject being a smoker. Starts from the first time he became a smoker until the time of this study. While the number of cigarettes per day was defined as the average number of cigarettes smoked in one day. Working period was defined as the duration of subject's military duty starting from the year of entrance until the time of this study.

This study received ethical clearance from Research Ethic Committee of Faculty of Medicine of the University 
of Indonesia. Data were analised by Cox regression test using STATA 9.0 program. ${ }^{8,9}$

\section{RESULTS}

In this study we had 177 participants ranging from 2144 years old. Most of the participants were under 30 years of age $(67.23 \%)$, and most of them were trainees. Working period ranged from 6 to 10 years, and the higher number of enterance were years between 1996-2000.

The insidence of BM was $56.5 \%$. The case and noncase of BM were likely similarly distributed in terms of age. However, more BM cases than non BM case in terms of flight engineer crew or freefall compare with trainnees. Subjects who had longer than shorter working period were more likely to be BM.

Subject who were still smoking or smoking 11-20 cigarettes a day or with a Brickman index of 1-312 were at a higher risk of BM compared with non smokers.
ENT disorders such as pharyngitis was found in 35\%, of subjects, rhinitis was found in $20.9 \%$ of subjects and tonsillitis was found in only $2.3 \%$ of subjects. In this study we did not find sinusitis or suspected sinusitis. It is likely that ENT disorders were the same in $\mathrm{BM}$ cases and in non-BM cases.

Septal deviation, long working period, smoking period and qualification were the dominant risk factors for BM. Subjects who had septal deviation had a moderately increased risk for BM at $23 \%$. In terms of working period, there was an increased trend of $\mathrm{BM}$ related to longer working periods. However, among longer durating of smoking habits there was a decrease of BM risk. In term of smoking periods, those who have smoked for 1-3 years had $68 \%$ and those who have smoked for 4-20 years had 32\% higher risk for BM. On the other hand, trainees had $40 \%$ higher risk for $\mathrm{BM}$ than flight engineers or freefall subjects.

Table 1. Several demographic, task and risk of Barotitis media

\begin{tabular}{|c|c|c|c|c|c|c|c|}
\hline & \multicolumn{4}{|c|}{ Barotitis media } & \multirow{3}{*}{$\begin{array}{c}\text { Crude } \\
\text { Relative } \\
\text { Risk }\end{array}$} & \multirow{3}{*}{$\begin{array}{l}95 \% \text { confidence } \\
\text { interval }\end{array}$} & \multirow{3}{*}{$\mathrm{P}$} \\
\hline & \multicolumn{2}{|c|}{$\begin{array}{c}\text { No } \\
(\mathrm{n}=77)\end{array}$} & \multicolumn{2}{|c|}{$\begin{array}{c}\text { Yes } \\
(n=100)\end{array}$} & & & \\
\hline & $\mathrm{N}$ & $\%$ & $\mathrm{n}$ & $\%$ & & & \\
\hline \multicolumn{8}{|l|}{ Age } \\
\hline 21-30 years & 57 & 47.9 & 62 & 52.1 & 1.00 & Reference & \\
\hline $31-44$ years & 20 & 34.5 & 38 & 65.5 & 1.26 & $0.84-1.88$ & 0.266 \\
\hline \multicolumn{8}{|l|}{ Entrance year } \\
\hline $2002-2006$ & 35 & 55.6 & 28 & 44.4 & 1.00 & Reference & \\
\hline $1997-2001$ & 25 & 38.5 & 40 & 61.5 & 1.38 & $0.85-2.24$ & 0.187 \\
\hline $1984-1996$ & 17 & 34.7 & 32 & 65.3 & 1.47 & $0.89-2.44$ & 0.137 \\
\hline \multicolumn{8}{|l|}{ Smoking habit } \\
\hline No & 33 & 55.9 & 26 & 44.1 & 1.00 & Reference & \\
\hline Quit smoking & 19 & 43.2 & 25 & 56.8 & 1.29 & $0.75-2.23$ & 0.364 \\
\hline Still smoking & 25 & 33.8 & 49 & 66.2 & 1.50 & $0.93-2.42$ & 0.093 \\
\hline \multicolumn{8}{|l|}{ Cigarette per day } \\
\hline No & 33 & 55.9 & 26 & 44.1 & 1.00 & Reference & \\
\hline $1-10$ bar & 37 & 40.2 & 55 & 59.8 & 1.32 & $0.83-2.09$ & 0.241 \\
\hline $11-20$ bar & 7 & 26.9 & 19 & 73.1 & 1.62 & $0.90-2.92$ & 0.105 \\
\hline \multicolumn{8}{|l|}{ Brickman index } \\
\hline $0 \quad$ bar-year & 33 & 55.9 & 26 & 44.1 & 1.00 & Reference & \\
\hline $1-312$ bar-year & 44 & 37.3 & 74 & 62.7 & 1.39 & $0.89-2.16$ & 0.147 \\
\hline \multicolumn{8}{|l|}{ Preventive behaviour } \\
\hline Appropriate time & 72 & 43.9 & 92 & 56.1 & 1.00 & Reference & \\
\hline Too late & 5 & 38.5 & 8 & 61.5 & 1.10 & $0.53-2.26$ & 0.802 \\
\hline
\end{tabular}


Table 2. Selected medical factors and risk of Barotitis media

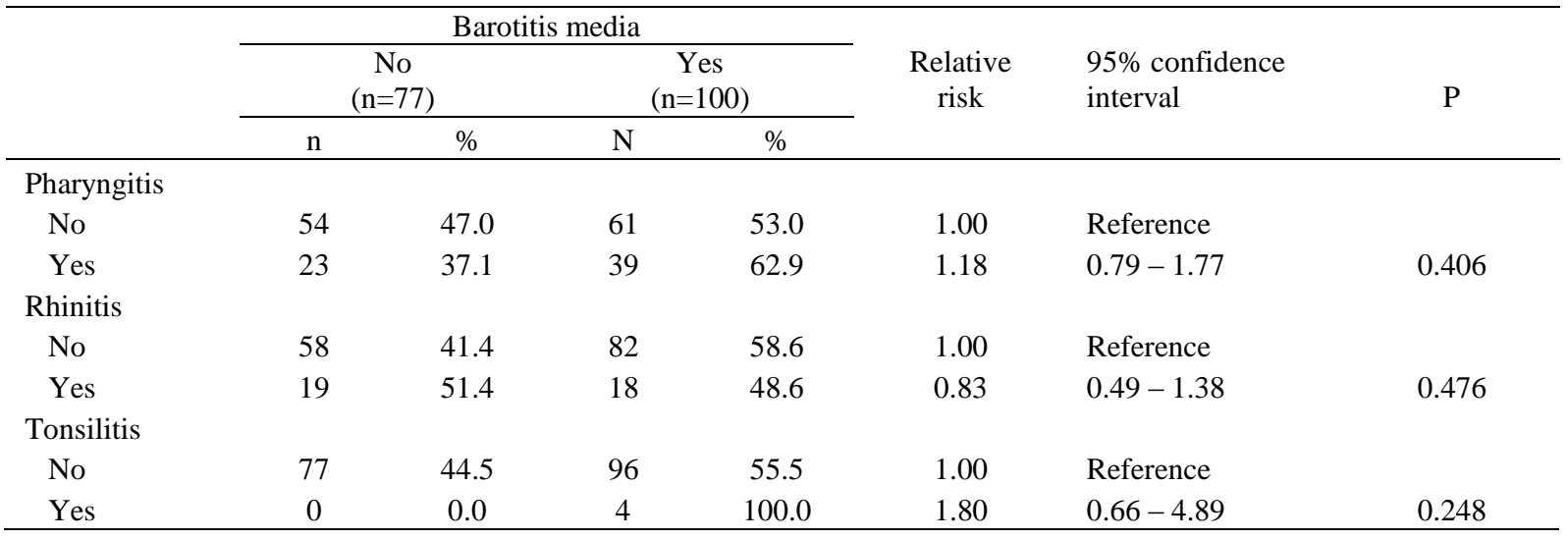

Table 3. Relationship between septum deviation, duration of work, smoking habits, qualifiation, and risk of Barotitis media

\begin{tabular}{|c|c|c|c|c|c|c|c|}
\hline & \multicolumn{4}{|c|}{ Barotitis media } & \multirow{3}{*}{$\begin{array}{l}\text { Relative } \\
\text { risk } \\
\text { adjusted }\end{array}$} & \multirow{3}{*}{$\begin{array}{l}95 \% \text { confidence } \\
\text { interval }\end{array}$} & \multirow{3}{*}{$\mathrm{P}$} \\
\hline & \multicolumn{2}{|c|}{$\begin{array}{c}\text { No } \\
(\mathrm{n}=77)\end{array}$} & \multicolumn{2}{|c|}{$\begin{array}{c}\text { Yes } \\
(n=100)\end{array}$} & & & \\
\hline & $\mathrm{N}$ & $\%$ & $\mathrm{~N}$ & $\%$ & & & \\
\hline \multicolumn{8}{|l|}{ Septal } \\
\hline No & 57 & 45.2 & 69 & 54.7 & 1.00 & Reference & \\
\hline Ya & 20 & 39.2 & 31 & 60.7 & 1.23 & $0.95-1.60$ & 0.123 \\
\hline \multicolumn{8}{|l|}{ Working period } \\
\hline 1 - 5 years & 35 & 55.6 & 28 & 44.4 & 1.00 & Reference & \\
\hline $6-10$ years & 25 & 38.5 & 40 & 61.5 & 1.45 & $1.03-2.04$ & 0.031 \\
\hline $11-23$ years & 17 & 34.7 & 32 & 65.3 & 1.57 & $1.08-2.27$ & 0.017 \\
\hline \multicolumn{8}{|c|}{ Time of smoking } \\
\hline No & 31 & 42.5 & 26 & 24.7 & 1.00 & Reference & \\
\hline $1-3$ years & 18 & 24.7 & 28 & 30.1 & 1.68 & $1.17-2.42$ & 0.005 \\
\hline $4-20$ years & 24 & 32.9 & 42 & 45.2 & 1.32 & $0.94-1.84$ & 0.106 \\
\hline \multicolumn{8}{|c|}{ Special Qualification } \\
\hline JMU/Freefall & 30 & 57.7 & 22 & 42.3 & 1.00 & Reference & \\
\hline Trainees & 47 & 37.6 & 78 & 62.4 & 1.40 & $0.99-1.97$ & 0.051 \\
\hline
\end{tabular}

* Adjusted intervariable in this table

\section{DISCUSSION}

In interpreting this study there were several limitations, among others: (1) most of the subjects were trainees so there is a possibility that they did not answer honestly as they want to pass the test; (2) The number of tonsillitis was very small, making it difficult to interpret the results; (3) there was no criteria for degree of septal deviation, therefore we have no data to analize the relationship between the degree of septal deviation and BM. However, this study was conducted in an international standardized aviation medicine institution and performed by an expert or specialist in aviation medicine.
In this study we noted a high incidence of BM at $56.5 \%$ with septal deviation which moderately increased the risk of $\mathrm{BM}(\mathrm{p}=0.123)$. This high incidence of $\mathrm{BM}$ was related to the extreme condition that occured during the training session and was in acordance with a previous study by Miyazawa et al. that states that ET function will decrease with exposure of extreme change of atmospheric pressure. ${ }^{10}$ The high and fast pressure change in this HAHO training simulation was considered as the extreme condition. Therefore, it is understandble that the incidence of BM was high in this study. 
Based on the previous training session, septal deviation had a large effect on BM. On the other hand, this study noted that septal deviation had moderately incrased the risk of $\mathrm{BM}(\mathrm{p}=0.123)$. This result was not in accordance with literarture that state that septal deviation may be a significant risk factor in certain conditions, meaning that septal deviation is not a dominant factor. ${ }^{1}$ Septum deviation is an abnormal condition of the septum that has individual variations depending on the cause. Thus, the degree of septal deflection in each case can be different. This condition may result in different effects on ET. At present time, there is no standard criteria to differentiate the degree of deflection in septal deviation and this study can only differentiate septal deviation by stating wether there was or there was not septal deviation.

Other ENT disorder such as pharyngitis, rhinitis, tonsilitis and sinusitis failed to show that they increased the risk of BM. In the literature, pharyngitis is a dominant factor, ${ }^{1-3,6}$ but in this study it was not noted. Severe pharyngitis was excluded in this study and there were only pharyngitis with little complications included. From the results we can see that mild pharyngitis was not likely accompanied by inflammation of the $\mathrm{ET}$, therefore the risk of BM was not increased by this factor.

Rhinitis was also not proven to be a factor that increases the risk of BM, although in Sven-eric Stangerup BM study of commercial flight passengers revealed that nasal congestion could be a predisposing factor. ${ }^{3}$ In this study, rhinitis cases found were mostly without complaint of nasal congestion. Besides that, for the safety matter, severe rhinitis cases were excluded. This difference most likely made this different result. This study shows that mild rhinitis without nasal congestion did not increase the risk of $\mathrm{BM}$ in HAHO training.

Tonsilitis is a condition that may develop into an abscess or only a mild inflammation. A previous study shows that limfoid hipertrophy at the nasopharyng may be the cause of recurrent BM. ${ }^{1}$ However, this study failed to prove that tonsillitis was a dominant risk factor to increase the risk of $\mathrm{BM}$ due to the small number of cases.

We did not find a sinusitis case in this study. None of the subjects had a suspicious condition that can lead to sinusitis. This could happen because the evaluation of sinusitis was performed only by routine examination and history anamnesis without radiographic examination so the subject condition cannot be accurately evaluated.
Working period was proven to be one of the factors that increased the risk of $\mathrm{BM}$. The longer working period, the higher the risk of BM. Even though all the subjects in this study were TNI members that have gone through good physical selection, but the heavy work load could be the exposure that decreased their physical performance. Most of the participants were freefall and flight engineers. Flight engineer and freefall subjects may have the same risk for pressure change exposure.

Some of the trainees in the flight engineer selection program has long been assistants to flight engineers before and they already have had exposure to pressure changes like flight engineers. The longer period of work, the amount of exposure was increased and the ET function was decreased. This history of recurrent exposure could be a factor to increase the risk of BM in relations to working period.

The qualification of the subjects were proven to increase the risk of BM. Someone with flight engineer or freefall qualifications had lower risk of BM compare to the trainees. This proved that qualification was related to the ability of a person to deal with $\mathrm{BM}$ problems. A person with qualifications has gone through a selection that made him better than others. After training, he will have better skill than a person without qualifications. This will decrease the risk of BM because, besides the training that they received, theyare more experienced than others to handle BM matters.

The experience in aviation medicine and indoctrination made them (flight engeneer and freefall) have more skills to prevent BM. This is shown in the incomparability of working period and qualifications. In this relationship we can see that even a participant with longer working period does not necessarily assure that he has better skills.

This study proved that smoking increased the risk of BM. Smokers who have been smoking for 1-3 years had $68 \%$ higher risk than non smokers and 36\% higher risk compared to those who have been smoking for 4-20 years. Smoking for 4-20 years will increase the risk of BM moderately $(\mathrm{p}=0.106)$. This could happen because the smoke irritates the mucous tissue of the upper respiratory tract leading to inflammation reaction with swelling. At the chronic phase, the inflammation is still going on followed by the destruction of cells through the healing process developed to repair the damaged, but there is no more inflammation like in the acute phase. ${ }^{11-2}$ 


\section{CONCLUSION}

Incidence of BM in HAHO training is high at $56.5 \%$. In HAHO training septal deviation, working period longer than 5 years, smoking habits for 1-3 years and special qualifications were the dominant factors that increased the risk of BM. Participants who had working periods of more than 5 years, smoking habits for 1-3 years and without special qualifications need to undergo special preparations to minimize the risk of BM.

\section{Acknowledgent}

We thank the Chief of Lakespra for his permission to publish the study results. Special gratitudes to all participants who cooperatively participated this study.

\section{REFERENCES}

1. McQueen WJ, Marini JS. The otolaryologic aspects of aerospacemedicine In: The Ultimate Flight Surgeon Reference (CD-ROM). Joint produced of US Navy, US Army, $3^{\text {rd }}$ Edition, 2001.

2. Harril WC. Barotrauma of the middle and inner ear [monograf di internet]. Houston: Baylor College of Medicine; 1995 [diambil 12 Februari 2007]. Available from : http://www.bcm.edu/oto/grand/32395.html.

3. Brooksidepress.org[homepage di internet]. Aviation Ear Neck and Throat Medicine.[diambil 13 Maret 2007]. Tersedia di : http://www.brooksidepress.org/Products/ OperationalMedicine/DATA/operationalmed/Operational
Settings/naval\%20Aviation\%20Medicine/AviationEarNos eandThroatMedicine.htm.

4. Stangerup SE, Tjernstrom Ö, Klokker M, Harcourt J, Stockholm J. Point prevalence of barotitis in children and adults after flight, and effect of autoinflation. Aviat, Space, and Environ Med. 1998; 69:45-9.

5. Basu A. Middle ear pain and trauma during air travel. Clin Evid. 2006;15:1-2.

6. Alatas H dkk. Desain penelitian. Dalam: Sastroasmoro S, Ismael S. Dasar-dasar metodologi penelitian klinis, ed kedua. Jakarta. Sagung seto; 2002: 79-95, 247.

7. Direktorat Kesehatan TNI AU. Buku dasar-dasar ilmu kesehatan penerbangan jilid II. Jakarta. 1995..

8. Hosmer DW, Lemeshow S. Applied survival analysis. $2^{\text {nd }}$ Ed New York: John Wiley \& Sons; 2000.

9. Barros AJD, Hirakata VN. Alternative for logistic regression in cross-sectional studies: an empirical comparison that directly estimates the prevalence ratio. BMC Medical Research Methodology [serial online]. Oct. 2003 [cited 2007 Aug 1]; 3 (21): [13 p]. Available from: http//www.biomedcentral.com/1471-2288/3/21].

10. Ueda H, Miyazawa T, Yanagita N. Eusthacian tube function and middle ear barotrauma associated with extremes in atmospheric pressure. Ann Ottol Rhinol Laryngol. 1996; 105: 887-92.

11. Ward PA, Inflamasi, Dalam: Wahab AS, alih bahasa, Soeripto N, editor. Imunologi III. Terjemahan dari Bellanti JA. Imunologi III.Yogyakarta,Gadjah Mada University Press; 1993: 223-33.

12. Wikipedia[situs internet] Chronic inflamation. [diambil tanggal 10 November 2007] Tersedia di: http://en.wikipedia.org/ wiki/Inflammation\#Chronic_inflammation

13. Maran AGD, Lund VJ. Clinical rhinology. New York. Thieme Medical Publishers; 1990: 116.

14. Vincent MT, Celestin N, Hussain A. Pharyngitis. American Family Physician. 2004; 69: 1465-1470. 